\title{
Pengaruh Jumlah Sudu Terhadap Kinerja Turbin Savonius
}

\author{
Jamal Jamal ${ }^{1, a}$ \\ ${ }^{1}$ Jurusan Teknik Mesin, Politeknik Negeri Ujung Pandang, Jln Perintis Kemerdekaan Km. 10 Makassar 90245 Indonesia \\ ajamal_mesin@poliupg.ac.id
}

\section{(c) (†) (O)}

Abstract - Savonius wind turbines are wind turbines that can operate at low wind speeds, this type of turbine is very suitable to be used in several places in Indonesia. The research aims to improve the performance of the Savonius wind turbine with variations in the number of turbine blades as well as variations in the velocity of wind speed. The research method was experimental where wind turbine testing was carried out with variations in the number of turbine blades with number of 2,3 and 4 blades, other variations carried out were wind speed at 3.5 ; 4,$5 ; 5.5$ and $6.5 \mathrm{~m} / \mathrm{s}$. The study results show that the 2-blade turbine produces greater rotation, but the torque moment is lower than the 3 and 4 blade turbines, this can be seen in the low efficiency of the 2 blade turbine at low wind speeds with high loading. At $3.5 \mathrm{~m} / \mathrm{s}$ wind turbines 2 blade turbines have efficiency that tends to be the same as 3 and 4 blade turbines up to $0.5 \mathrm{~N}$ but at loads of $0.6-1.2 \mathrm{~N} 2$ blade turbines have lower efficiency, while at wind speeds of $4.5-6.5 \mathrm{~m} / \mathrm{s} 2$ blade turbines have greater efficiency than turbines 3 and 4 blades up to a load of $1.2 \mathrm{~N}$ but if the load is added then the efficiency of 2-blade turbines can be smaller than efficiency 3 and 4-blade.

Keywords-Turbine; Savonius; Variation; Blade

\footnotetext{
Abstrak-Turbin angin Savonius adalah turbin angin yang dapat beroperasi pada kecepatan angin yang rendah, turbin jenis ini sangat tepat digunakan untuk beberapa tempat di Indonesia. Penelitian bertujuan untuk meningkatkan kinerja turbin angin Savonius dengan variasi jumlah sudu turbin serta serta variasi kecepatan aliran udara. Metode penelitian adalah eksperimental dimana dilakukan pengujian turbin angin savonius dengan variasi jumlah sudu turbin yaitu 2, 3 dan 4 sudu, variasi lain yang dilakukan adalah kecepatan angin yaitu 3,$5 ; 4,5 ; 5,5$ dan 6,5 $\mathrm{m} / \mathrm{s}$. Penelitian hasil bahwa turbin 2 sudu menghasilkan putaran yang lebih besar, tetapi momen torsi yang rendah dibandingkan turbin 3 dan 4 sudu, hal ini terlihat pada rendahnya efisiensi turbin 2 sudu pada kecepatan angin rendah dengan pembebanan tinggi. Pada kecepatan angin $3,5 \mathrm{~m} / \mathrm{s}$ turbin 2 sudu memiliki efisiensi yang cenderung sama dengan turbin 3 dan 4 sudu hingga beban 0,5 $\mathrm{N}$ tetapi pada beban $0,6-1,2 \mathrm{~N}$ turbin 2 sudu memiliki efisiensi yang lebih rendah, sedangkan pada kecepatan angin $4,5-6,5 \mathrm{~m} / \mathrm{s}$ turbin 2 sudu memiliki efisiensi yang lebih besar dari turbin 3 dan 4 sudu hingga beban 1,2 $\mathrm{N}$ tetapi jika beban ditambah maka efisiensi turbin 2 sudu dapat lebih kecil dari efisiensi 3 dan 4 sudu.
}

Kata Kunci-Turbin; Savonius; Variasi; Sudu.

\section{Pendahuluan}

Angin adalah udara yang bergerak dari daerah bertekanan tinggi ke daerah bertekanan lebih rendah. Pergerakan angin inilah yang dapat dimanfaatkan sebagai salah satu sumber energi dengan mengkonversi menjadi energi lainnya. Cara konversi energi angin menjadi energi makanik dapat dilakukan dengan menggunakan turbin angin savonius.

Energi angin sebelum melewati turbin angin disebut juga energi input turbin. Energi angin yang melewati turbin tidak semuanya dapat dikonversi menjadi energi mekanik [1]. Energi yang dibangkitkan turbin setelah menerima energi angin disebut energi mekanik yang biasa juga disebut dengan energi output turbin.

Penelitian turbin angin savonius dengan berbagai jumlah sudu telah banyak dilakukan diantaranya adalah penelitian tentang turbin Savonius dengan 3 buah sudu diperoleh efisiensi mekanik 76\% [2]. Penelitian lainnya adalah variasi jumlah sudu turbin 2, 3 dan 4 buah pada turbin savonius tipe $\mathrm{L}$, diperoleh 3 sudu memiliki efisiensi terbaik dan 4 sudu memiliki efisiensi terendah [3]. Penelitian lainnya pada turbin angin Savonius adalah variasi 2 dan 3 sudu dan menggunakan Guide Vane, diperoleh hasil penggunaan 2 sudu memiliki kinerja optimum [4].

Penelitian dengan variasi turbin pada turbin Savonius juga telah dilakukan yaitu perbandingan turbin Savonius tipe $U$ dengan tipe $L$, dengan ukuran windside besar dan kecil [5]. Penelitian turbin tipe $\mathrm{L}$ juga dilakukan dengan variasi jumlah sudu yaitu 2, 3 dan 4 sudu [3]. Penelitian 
lainnya adalah variasi sudut kelengkungan sudu turbin Savonius tipe L, diperoleh hasil sudut kelengkungan $20^{\circ}$ memiliki kinerja optimum [6].

Penelitian turbin Savonius dengan pada kecepatan angin rendah juga telah diamati, diperoleh kinerja turbin Savonius berada pada efisiensi dengan kisaran 4,8\% $14,5 \%$ [7]. Penelitian turbin Savonius lainnya adalah turbin Savonius bertingkat dengan variasi jumlah sudu turbin 2 [8], 3 dan 4 sudu, penelitian ini turbinnya bertingkat dua dimana jumlah turbin pada tingkat satu dan dua dapat sama maupun berbeda jumlah sudunya [9]. Penelitian turbin savonius yang fokus pada sudu juga telah dilakukan yaitu penelitian variasi jarak celah sudu turbin yaitu 1, 2 dan $3 \mathrm{~cm}$, diperoleh jarak celah 1 $\mathrm{cm}$ menghasilkan kinerja optimum [10]. Penelitian lainnya adalah tentang pengaruh kelengkungan sudu terhadap unjuk kerja turbin angin Savonius, diperoleh hasil bahwa kelengkungan sudu juga berpengaruh terhadap kinerja turbin angin Savonius [11].

Penelitian turbin savonius hibrid dengan turbin lainnya atau dengan sistem pembangkit lainnya juga telah dilakukan yaitu hibrid antara turbin Savonius dan turbin Darrieus [12]. Penelitian lainnya adalah hibrid antara turbin Savonius dengan sel surya untuk pembangkit listrik [13].

\section{Metode Penelitian}

Penelitian dilakukan dengan metode eksperimental untuk mengetahui kinerja dari tubin savonius dengan variasi jumlah sudu turbin, jumlah sudu turbin yang akan digunakan adalah 2, 3 dan 4 buah sudu seperti terlihat pada gambar 1. Dalam pengujian juga dilakukan variasi kecepatan angin yaitu $3,5 \mathrm{~m} / \mathrm{s}, 4,5 \mathrm{~m} / \mathrm{s}, 5,5 \mathrm{~m} / \mathrm{s}$ dan 6,5 $\mathrm{m} / \mathrm{s}$.
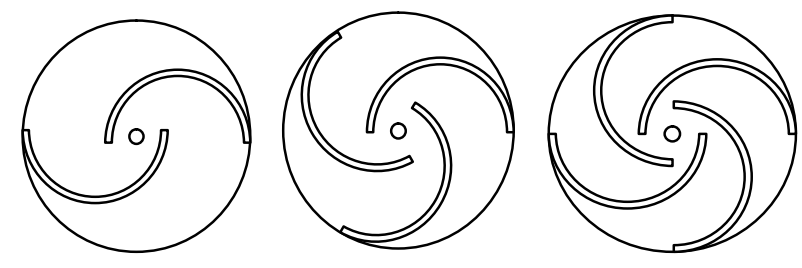
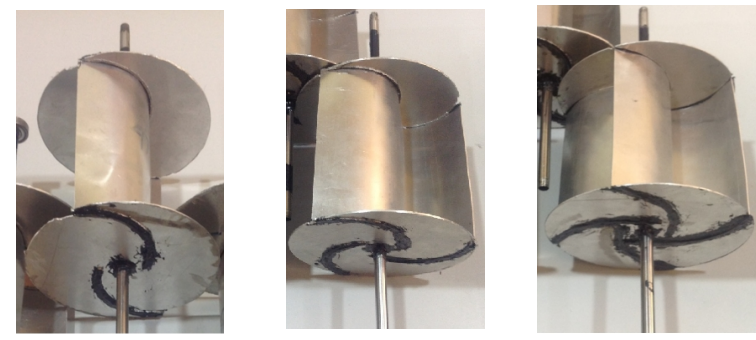

Gambar 1. Turbin Savonius variasi jumlah sudu

Dalam melakukan pengujian diperlukan sistem pengujian atau rangkaian instrumentasi pengujian yang terdiri dari kipas angin sebagai sumber angin yang dapat di atur kecepatan alirannya. Agar alirannya terjaga, maka aliran udara akan dilewatkan melalui terowongan angin menuju keturbin savonius melewati sudu pengarah. Turbin akan ditopang oleh poros dan didudukkan pada bearing sebagai titik putar poros. Adapun pembebanan berfungsi untuk mengukur daya output mekanik, adapun instalasi pengujian dapat dilihat pada gambar 2 .
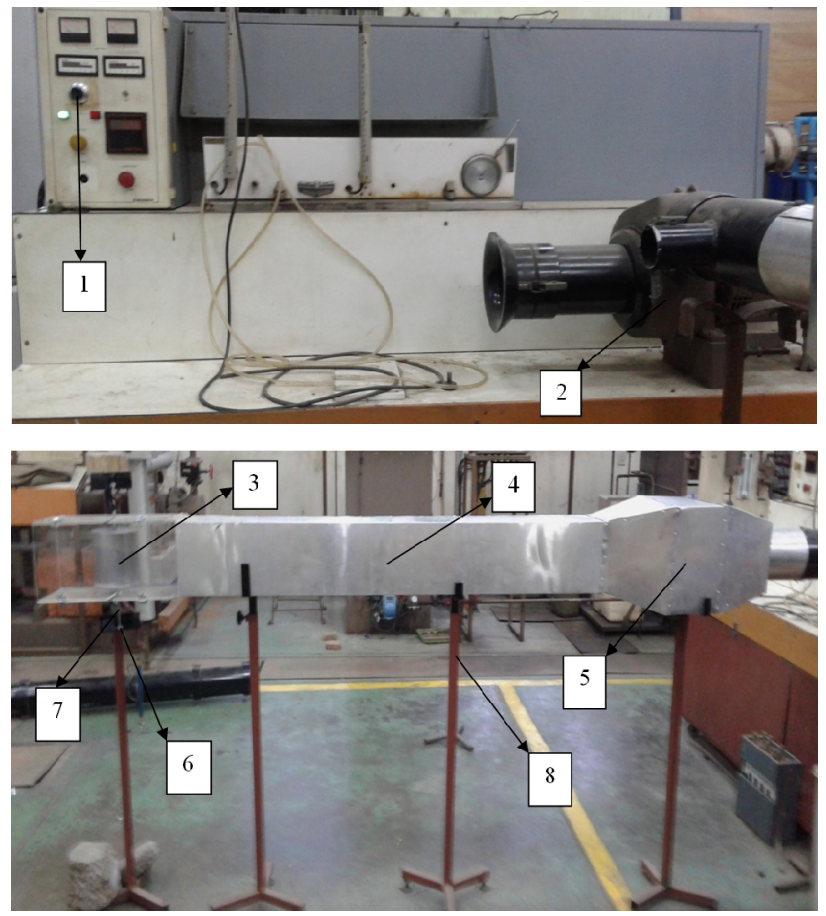

Gambar 2. Instalasi pengujian

(1. Pengatur kec. angin; 2. Sumber angin; 3. Turbin angin;

4. Lorong angin; 5. Salurang pengarah angin; 6. Bearing;

7. Poros; 8. Rangka)

Dalam pengujian membutuhkan alat ukur berupa pegas newton untuk memberikan beban gaya pada poros turbin sehingga dapat dihitung beban torsi, juga dibutuhkan tachometer untuk mengukur putaran dan 
anemometer untuk mengukur kecepatan angin, alat ukur yang digunakan dapat dilihat pada gambar 3 .

Pengujian turbin savonius untuk mendapatkan besar kinerja turbin dengan variasi jumlah sudu turbin dan kecepatan aliran udara. Kinerja turbin dapat dilihat dari besar efisiensinya, merupakan perbandingan daya output terhadap daya input.

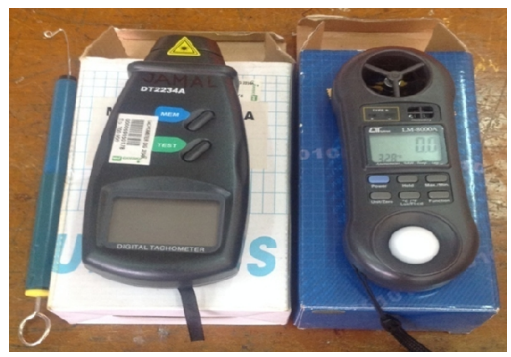

Gambar 3. Alat ukur Pegas Newton, Tachometer dan Anemometer

Daya input turbin diperoleh dari pengukuran laju aliran udara dan luas permukaan penampang turbin yang menerima aliran udara. Daya input akan divariasikan dengan memvariasikan laju aliran udara.

Daya output turbin yang akan diukur adalah daya mekanik diperoleh dari besar momen torsi dan pengukuran kecepatan putaran turbin, momen torsi akan diperoleh dengan mengukur besar beban gaya yang diberikan terhadap turbin.

\section{Hasil dan Pembahasan}

Pada gambar 4 diperoleh bahwa semakin besar beban mekanik (F) maka putaran output turbin semakin kecil, dan semakin besar kecepatan angin maka putaran output turbin juga semakin besar.

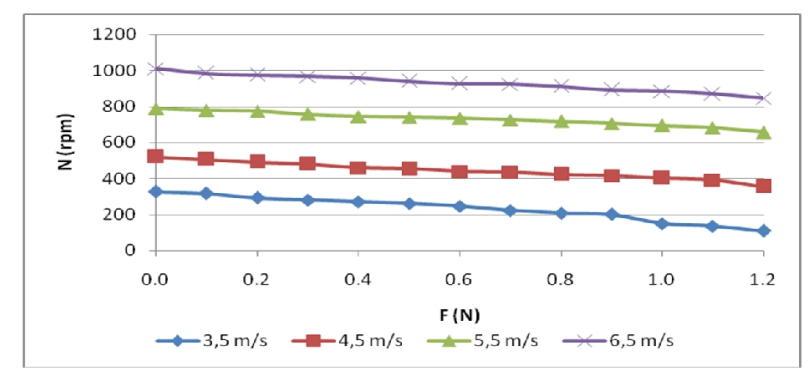

Gambar 4. Hubungan beban terhadap putaran turbin dengan berbagai kecepatan angin pada turbin 2 sudu.
Pada gambar 4 menunjukkan bahwa pada turbin dengan 2 sudu dengan pembebanan $0-1,2 \mathrm{~N}$ untuk kecepatan angin $3,5 \mathrm{~m} / \mathrm{s}$ diperoleh putaran turbin sebesar 0 - $327 \mathrm{rpm}$, pada kecepatan $4,5 \mathrm{~m} / \mathrm{s}$ diperoleh putaran 0 - 520,4 rpm, pada 5,5 m/s diperoleh $0-788,5 \mathrm{rpm}$ dan pada $6,5 \mathrm{~m} / \mathrm{s}$ diperoleh $0-1012 \mathrm{rpm}$. Pada turbin dengan 3 dan 4 sudu, juga diperoleh kecenderungan yang sama.

Pembebanan memberikan tahanan mekanik (gesek) pada poros turbin sehingga peningkatan beban mengakibatkan penurunan putaran poros turbin.

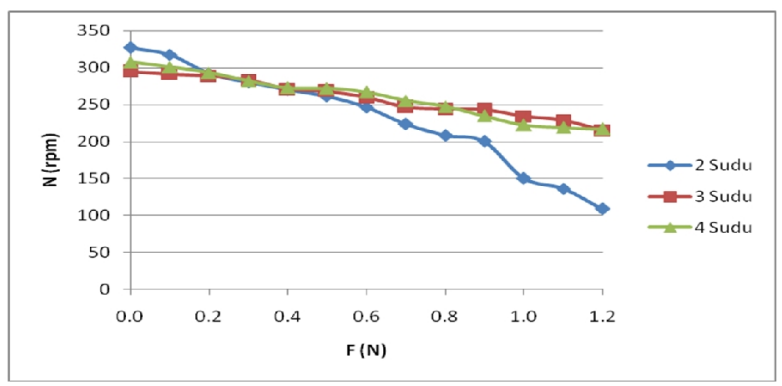

Gambar 5. Hubungan beban terhadap putaran turbin dengan berbagai jumlah sudu turbin pada kecepatan angin $3,5 \mathrm{~m} / \mathrm{s}$.

Pada gambar 5 diperoleh bahwa pada turbin dengan 2 sudu dengan semakin besarnya beban maka penurunan putaran turbin lebih cepat dibandingkan pada turbin dengan 3 dan 4 sudu, hal ini membuktikan bahwa pada turbin dengan 2 sudu putaran yang dihasilkan besar tetapi torsinya kecil sebaliknya terjadi pada turbin dengan 3 dan 4 sudu. Penggunaan turbin dengan 3 dan 4 sudu memberikan kecenderungan yang sama, tetapi putaran turbin dengan 3 sudu lebih besar dari 4 sudu dengan torsi yang cenderung sama.

Pada gambar 5 menunjukkan bahwa pada kecepatan angin $3,5 \mathrm{~m} / \mathrm{s}$ dengan pembebanan $0-1,2 \mathrm{~N}$ untuk turbin dengan 2 sudu diperoleh putaran turbin sebesar 0 - $327 \mathrm{rpm}$, pada turbin dengan 3 sudu diperoleh putaran turbin 0 - 294,6 rpm, pada 4 sudu diperoleh $0-307,7$ $\mathrm{rpm}$. Pada kecepatan angin $4,5 \mathrm{~m} / \mathrm{s}$ dan $5,5 \mathrm{~m} / \mathrm{s}$ serta 6,5 $\mathrm{m} / \mathrm{s}$ diperoleh kecenderungan sama. 


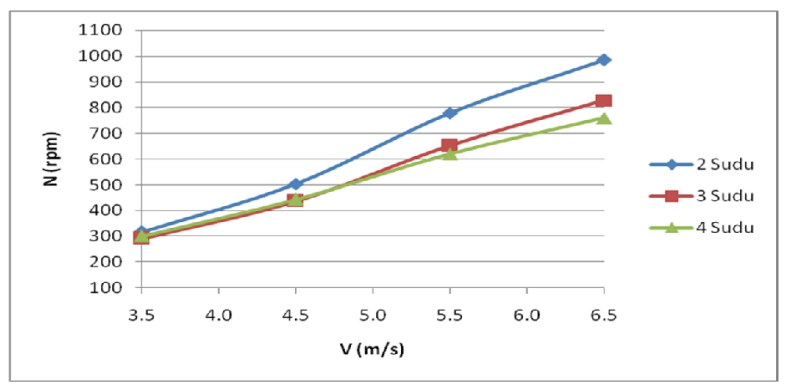

Gambar 6. Hubungan kecepatan angin terhadap putaran turbin dengan berbagai sudu pada kondisi tanpa beban.

Pada gambar 6 diperoleh bahwa pada turbin dengan 2 sudu dengan semakin besarnya kecepatan angin maka terjadi peningkatan putaran turbin yang lebih besar dibandingkan pada turbin dengan 3 dan 4 sudu. Turbin dengan 3 sudu memberikan putaran yang lebih besar dibandingkan dengan 4 sudu kecuali pada kecepatan angin $4,5 \mathrm{~m} / \mathrm{s}$.

Pada gambar 6 menunjukkan bahwa pada kondisi tanpa beban $(0 \mathrm{~N})$ dengan kecepatan angin $3,5-6,5 \mathrm{~m} / \mathrm{s}$ untuk turbin dengan 2 sudu diperoleh putaran turbin 327 - 1012 rpm, pada turbin dengan 3 sudu diperoleh putaran 294,6 - 832,1 rpm dan pada turbin dengan 4 sudu diperoleh 307,7 - 766,5 rpm. Pada pembebanan sebesar 0,1-1,2 $\mathrm{N}$ diperoleh kecenderungan yang sama.

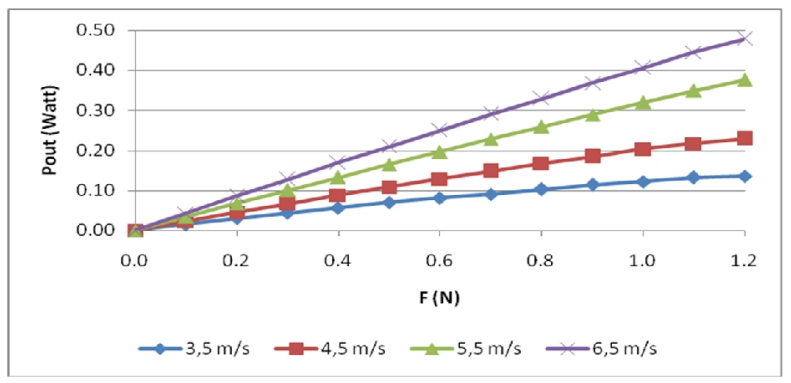

Gambar 7. Hubungan beban terhadap daya keluaran dengan berbagai kecepatan angin pada turbin 3 sudu.

Pada gambar 7 diperoleh bahwa semakin besar beban mekanik maka daya keluaran (Pout) semakin besar, juga diperoleh hasil bahwa semakin besar kecepatan angin maka daya keluaran semakin besar.

Pada gambar 7 menunjukkan bahwa pada turbin 3 sudu dengan beban $0-1,2 \mathrm{~N}$ untuk kecepatan angin 3,5 $\mathrm{m} / \mathrm{s}$ diperoleh daya keluaran $0-0,135$ watt, pada $4,5 \mathrm{~m} / \mathrm{s}$ diperoleh $0-0,229$ watt, pada $5,5 \mathrm{~m} / \mathrm{s}$ diperoleh $0-$ 0,376 watt dan pada $4,5 \mathrm{~m} / \mathrm{s}$ diperoleh $0-0,478$ watt. Pada turbin 4 sudu diperoleh kecenderungan yang sama sedangkan pada turbin 2 sudu juga diperoleh kecenderungan yang sama kecuali pada kecepatan 3,5 $\mathrm{m} / \mathrm{s}$ diperoleh bahwa daya keluaran maksimum tidak terjadi pada beban $1,2 \mathrm{~N}$ tetapi pada beban $0,9 \mathrm{~N}$.

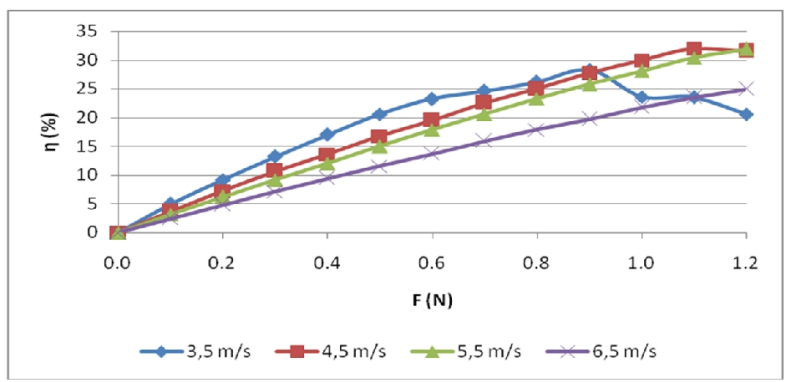

Gambar 8. Hubungan beban terhadap efesiensi dengan berbagai kecepatan angin pada turbin 2 sudu.

Pada gambar 8 untuk turbin 2 sudu dengan kecepatan angin $5,5 \mathrm{~m} / \mathrm{s}$ dan $6,5 \mathrm{~m} / \mathrm{s}$ diperoleh bahwa semakin besar beban maka efisiensinya semakin besar, pada kecepatan angin $3,5 \mathrm{~m} / \mathrm{s}$ semakin besar beban maka efisiensinya semakin besar hingga beban $0,9 \mathrm{~N}$ setelah itu peningkatan beban menurunkan efisiensi turbin sedangkan pada kecepatan angin $4,5 \mathrm{~m} / \mathrm{s}$ kenaikan efisiensi hingga beban $1,1 \mathrm{~N}$ setelah itu efisiensinya menurun dengan bertambahnya beban. Kecenderungan pada kecepatan 3,5 m/s akan terjadi pada kecepatan yang lain jika beban terus diperbesar.

Pada gambar 8 menunjukkan bahwa pada turbin 2 sudu dengan beban $0,1-1,2 \mathrm{~N}$ untuk kecepatan angin $3,5 \mathrm{~m} / \mathrm{s}$ diperoleh efisiensi $4,99-28,32 \%$, pada $4,5 \mathrm{~m} / \mathrm{s}$ diperoleh $3,73-31,95 \%$, pada $5,5 \mathrm{~m} / \mathrm{s}$ diperoleh $3,16-$ $31,92 \%$ dan pada $6,5 \mathrm{~m} / \mathrm{s}$ diperoleh $2,42 \%-24,92 \%$. Pada turbin 3 dan 4 sudu diperoleh kecenderungan yang sama.

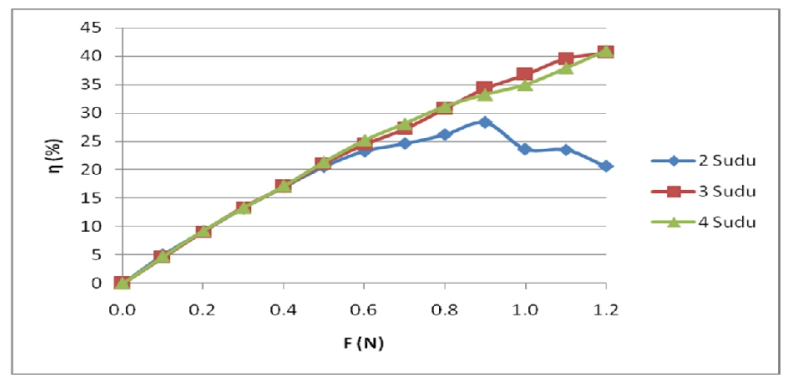

Gambar 9. Hubungan beban terhadap efesiensi dengan berbagai jumlah sudu turbin pada kecepatan angin $3,5 \mathrm{~m} / \mathrm{s}$.

Pada gambar 9 untuk kecepatan angin 3,5 m/s dengan turbin 3 dan 4 sudu diperoleh bahwa semakin besar 
beban maka efisiensinya semakin besar, pada turbin dengan 2 sudu semakin besar beban maka efisiensinya semakin besar hingga beban $0,9 \mathrm{~N}$ setelah itu peningkatan beban menurunkan efisiensi turbin. Kecenderungan pada turbin 2 sudu akan terjadi pada turbin 3 dan 4 sudu jika beban terus diperbesar maka efisiensinya suatu saat menurun dengan bertambahnya beban.

Pada gambar 9 menunjukkan bahwa pada kecepatan angin $3,5 \mathrm{~m} / \mathrm{s}$ dengan beban $0,1-1,0 \mathrm{~N}$ untuk turbin 2 sudu diperoleh efisiensi $4,99-28,32 \%$, pada turbin 3 sudu diperoleh efisensi $4,58-40,59 \%$ dan pada turbin 4 sudu diperoleh efisensi 4,73 - 40,95\%. Pada kecepatan angin $4,5 \mathrm{~m} / \mathrm{s}$ dan $5,5 \mathrm{~m} / \mathrm{s}$ serta $6,5 \mathrm{~m} / \mathrm{s}$ diperoleh kecenderungan yang sama terlebih jika pembebanan diteruskan hingga putaran turbin berhenti.

\section{Kesimpulan}

Berdasarkan hasil dan pembahasan maka dapat disimpulkan sebagai berikut:

1. Turbin 2 sudu menghasilkan putaran yang lebih besar dibandingkan turbin 3 dan 4 sudu, tetapi turbin 2 sudu memiliki momen torsi yang rendah dibandingkan turbin 3 dan 4 sudu, hal ini terlihat pada rendahnya efisiensi turbin 2 sudu pada kecepatan angin rendah dengan pembebanan tinggi.

2. Pada kecepatan angin $3,5 \mathrm{~m} / \mathrm{s}$ turbin 2 sudu memiliki efisiensi yang cenderung sama dengan turbin 3 dan 4 sudu hingga beban 0,5 $\mathrm{N}$ tetapi pada beban $0,6-1,2 \mathrm{~N}$ turbin 2 sudu memiliki efisiensi yang lebih rendah, sedangkan pada kecepatan angin 4,5 - 6,5 m/s turbin 2 sudu memiliki efisiensi yang lebih besar dari turbin 3 dan 4 sudu hingga beban 1,2 $\mathrm{N}$ tetapi jika beban ditambah maka efisiensi turbin 2 sudu dapat lebih kecil dari efisiensi 3 dan 4 sudu.
3. Daya output berbanding lurus dengan beban $(0,1$ $-1,2 \mathrm{~N})$ yang diberikan serta berbanding lurus dengan kecepatan angin $(3,5-6,5 \mathrm{~m} / \mathrm{s})$, sedangkan hubungannya dengan jumlah sudu turbin adalah memiliki kecenderungan yang sama dengan hubungan efisiensi terhadap jumlah sudu turbin.

\section{Daftar Pustaka}

[1] Ajao, K. R., and J. S. O. Adeniyi. "Comparison of Theoretical and Experimental Power output of Small 3-bladed Horizontalaxis Wind Turbine." Journal of American Science. Vol. 5 No. 4 (2009)

[2] Reksoatmodjo, Tedjo Narsoyo. "Vertical-Axis Differential Drag Windmill." Jurnal Teknik Mesin Vol. 6 No. 2 (2005)

[3] Mahendra, Bayu, Rudy Soenoko, and Djoko Sutikno. "Pengaruh Jumlah Sudu Terhadap Unjuk Kerja Turbin Angin Savonius Type L." Jurusan Teknik Mesin Fakultas Teknik, Universitas Brawijaya: Malang (2013).

[4] Ilham Fitranda, Robby. "Karakteristik turbin angin savonius 2 dan 3 blade dengan menggunakan bantuan guide vane." Jurnal Teknik Mesin Vol.2.No. 2 (2014).

[5] Soelaiman, F., Nathanael P. Tandian, and Nanang Rosidin. "Perancangan, Pembuatan dan Pengujian Prototipe SKEA Menggunakan Rotor Savonius dan Windside untuk Penerangan Jalan Tol." Bandung. ITB (2006).

[6] Dewi, Marizka Lustia. Analisis Kinerja Turbin Angin Poros Vertikal Dengan Modifikasi Rotor Savonius L Untuk Optimasi Kinerja Turbin. Diss. Universitas Sebelas Maret, 2010.

[7] Latif, Melda. "Efisiensi Prototipe Turbin Savonius pada Kecepatan Angin Rendah." Jurnal Rekayasa Elektrika 10.3 (2013).

[8] A. M. Shiddiq Yunus, A. Wahdah, Ulfa,"Modification and Testing of Wind Turbine with Double Savonius", Journal INTEK Vol. 3 No. 1, April (2016).

[9] Lewi Lewi, Jamal Jamal. "Analisis Kinerja Turbin Angin Savonius Bertingkat dengan Perubahan Variasi Jumlah Sudu Turbin." Seminar Nasional Hasil Penelitian (SNP2M PNUP) (2018).

[10] Setiawan, Andreas Andi, Rudy Soenoko, and Djoko Sutikno. "Pengaruh Jarak Celah Sudu terhadap Unjuk Kerja Turbin Angin Poros Vertical Savonius." (2012).

[11] Kusbiantoro, Andri, Rudy Soenoko, and Djoko Sutikno. "Pengaruh Panjang Lengkung Sudu Terhadap Unjuk Kerja Turbin Angin Poros Vertikal Savonius." Universitas Brawijaya. Malang (2013).

[12] Buana, Chandra, et al. "Uji Experimental Model Turbin Hybrid Savonius Bertingkat Dan Darrieus Tipe H Rotor." Jurnal Teknik Mesin SINERGI Vol.15 No. 2 (2017).

[13] Winarto, F. Eko Wismo. "Potensi Pembangkitan Listrik Hybrid Menggunakan Vertical Axis Wind Turbine Tipe Savonius dan Panel Sel Surya." Teknologi Vol. 6 (2013). 